\title{
PENGARUH PANDEMI COVID-19 TERHADAP DAMPAK IMPLEMENTASI EKONOMI DIGITAL PADA UMKM
}

\section{THE INFLUENCE OF THE COVID-19 PANDEMIC AGAINST THE IMPACT OF DIGITAL ECONOMY IMPLEMENTATION ON MSMES}

\author{
Rahmad Rahmadan ${ }^{1)^{*}}$, Indrawari ${ }^{2}$, Endrizal Ridwan ${ }^{3)}$ \\ 1*),2),3) Fakultas Ekonomi Universitas Andalas, Padang Indonesia. \\ ${ }^{1 *}$ Email: rahmad2an@gmail.com
}

\begin{abstract}
ABSTRAK: Implementasi Ekonomi digital sebagai dampak dari revolusi industri 4.0 dan Pandemi Covid-19 yang terjadi memberikan peluang dan tantangan pada sektor ekonomi. UMKM merupakan salahsatu yang harus diperhatikan karena murupakan salah satu pilar perekonomian Indonesia. Penelitian ini bertujuan untuk mengetahui sejauh mana pengaruh pandemi Covid-19 terhadap dampak implementasi ekonomi digital pada UMKM. Apakah implementasi ekonomi digital pada UMKM dapat menjadi salah satu alternatif untuk menghadapi kondisi tersebut? Implementasi Ekonomi Digital pada penelitian ini berupa pemanfaatan TIK dalam bentuk Digital Capital yang merupakan akumulasi pemanfaatan kopetensi digital dengan teknologi digital. Penelitian ini difokuskan kepada UMKM pada sektor kuliner di kota Padang yang telah beroperasi sebelum Covid-19 melanda Indonesia dan menjadikan minuman olahan kopi sebagai produk utamanya. Penelitian ini menggunakan analisis regresi linear berganda dengan bantuan Software StataMP 15. Hasil Penelitian ini menunjukan bahwa implementasi ekonomi digital berupa pemanfaatan TIK dalam bentuk Digital Capital berpengaruh signifikan terhadap pendapatan UMKM serta tidak terpengaruh oleh pandemic Covid-19 yang terjadi.
\end{abstract}

Kata Kunci: Pandemi Covid-19, Ekonomi Digital, TIK, UMKM, Pendapatan, Digital Capital

ABSTRACT: As a result of the industrial revolution 4.0 and the Covid-19 pandemic that occurred, the implementation of the digital economy provides opportunities and challenges in the economic sector. One thing that must be taken into account is MSMEs, since it is one of the pillars of the Indonesian economy. The aim of this study is to see the extent of the impact of the Covid-19 pandemic on the impact of the implementation of the digital economy on MSMEs. Can the implementation of the digital economy in MSMEs be an alternative to solving these conditions? The use of ICT in the context of Digital Capital, which is the cumulative use of digital competence with digital technology, is the implementation of the Digital Economy in this report. This study focuses on MSMEs operating before Covid-19 reached Indonesia in the culinary sector in the city of Padang, which is the main product of refined coffee drinks. With the help of StataMP 15 Software, this research uses multiple linear regression analysis. According the results of this study, the implementation of the digital economy in the form of the use of ICT in the form of Digital Capital has a significant effect on the revenue of MSMEs and is not affected by the occurrence of the Covid-19 pandemic.

Keywords: The Covid-19 Pandemic, Digital Economy, ICT, MSMEs, Revenue, Digital Capital

\section{A. PENDAHULUAN}

Revolusi industri 4.0. revolusi telah terjadi juga merubah model bisnis dan pola kompetisi tetapi juga merombak sistim ekonomi dan masyarakat serta membuat lingkungan ekonomi baru dimana teknologi digital memiliki peran di dalamnya (Afenya Millicent Selase, 2019). Perubahan yang terjadi semakin nyata disaat kondisi dunia yang dilanda pandemi Covid-19 yang berdampak pada seluruh sektor kehidupan manusia, tidak terkecuali pada sektor ekonomi (Baldwin dan Mauro, 2020). Kedua kondisi tersebut memberikan tantangan dan peluang terhadap pelaku usaha, 
khususnya UMKM. (Nida Masroor, 2019). Digitalisasi dengan menggunakan teknologi digital dalam bentuk internet pada teknologi informasi dan komunikasi merupakan salah satu bentuk revolusi 4.0 dan dapat digunakan untuk menghadapi tantangan dan memanfaatkan peluang yang ada. Teknologi ini meningkatkan konektivitas, interaksi manusia, mesin dan sumber daya lainnya. Dunia bergerak cepat ke arah sistem ekonomi yang didasarkan pada inovasi berkelanjutan dan luas yang sangat bergantung pada teknologi informasi dan komunikasi, di mana telekomunikasi membentuk komponen yang tidak terpisahkan untuk berinovasi (Schumpete, 1942 di dalam Chege, Wang dan Suntu, 2020). Internet menjadi suatu yang tidak terpisahkan dalam teknologi informasi dan komunikasi. Internet berkontribusi pada pertumbuhan ekonomi (Donou-Adonsou, 2019) hal ini membuat banyak inovasi yang melibatkan internet di sektor ekonomi.

Sektor ekonomi sudah seharusnya beradaptasi terhadap perkembangan teknologi terutama pada kondisi pandemic covid-19. Bentuk adaptasi sektor ekonomi terhadap perkembangan ini adalah terbentuknya Ekonomi Digital yang merupakan salah satu bentuk inovasi dalam bidang ekonomi. Ekonomi Digital yang terjadi di indonesia merupakan salah satu dampak perkembangan teknologi di Indonesia.

Jika melihat komposisi perekonomian Indonesia, UMKM harus tanggap dalam menghadapi perubahan yang sangat cepat ini, tidak hanya di perubahan tren pasar namun juga perkembangan teknologi tidak hanya di perubahan kondisi pasar namun juga perkembangan teknologi. UMKM mampu menyerap 96 persen tenaga kerja, serta berkontribusi sebesar 60 persen terhadap PDB nasional (Indrawan, 2019). Hal ini tentunya menjadikan transformasi digital pada bisnis UMKM suatu keharusan dan semakin penting serta patut untuk diperhatikan.

Transformasi digital pada bisnis UMKM menjadi semakin penting dan patut untuk diperhatikan. Transformasi ini harus segera dilakukan karena memiliki manfaat yang besar terhadap UMKM. Pesatnya perkembangan teknologi, telah mengubah perilaku masyarakat yang semakin mengarah ke digitalisasi. Pada saat sekarang perubahan prilaku masyarakat yang mengarah kepada digitalisasi juga didorong kondisi Pandemi Covid-19. Pemanfaaatan teknologi digital dapat digunakan untuk meningkatkan produktivitas khususnya penjualan pada sektor usaha diantaranya oleh UMKM (Rodriguez, Peterson dan Ajjan, 2015). Dengan banyaknya potensi yang dimiliki, serta manfaat dari penggunaan teknologi informasi dan komunikasi sebagai bentuk implementasi Ekonomi Digital oleh UMKM. Diantaranya dapat meningkatkan pendapatan (Helmalia dan Afrinawati, 2018) (Rodriguez, Peterson dan Ajjan, 2015).

Organisation for Economic Co-operation and Development (OECD) menginformasikan bahwa pandemic covid-19 berdampak serius pada perekonomian. Jika dilihat dari sisi penawaran terjadinya pengurangan pasokan bahan baku dan tenaga kerja oleh perusahaan. Dari sisi permintaan terjadinya penurunan permintaan barang yang dipengaruhi oleh upaya mengurangi konsumsi oleh masyarakat. Jika dilihat dari dunia usaha, UMKM merupakan salah satu sektor yang merasakan dampak lansung dari kondisi pandemic covid-19 (OECD, 2020).

Berdasarkan pada penjelasan diatas maka timbulah pertanyaan. Dengan banyaknya potensi yang dimiliki, serta manfaat dari penggunaan teknologi informasi dan komunikasi sebagai bentuk implementasi Ekonomi Digital oleh UMKM. Apakah implementasi ekonomi digital dalam bentuk pemanfaatan teknologi digital oleh UMKM dapat menjadi salah satu alternatif untuk menghadapi kondisi tersebut? Untuk itu penelitian ini akan melihat pengaruh Pandemi Covid-19 yang terjadi terhadap Dampak Implementasi Ekonomi Digital pada UMKM.

\section{B. KAJIAN PUSTAKA}

\section{Ekonomi Digital}

Konsep ekonomi digital pertama kali di perkenalkan oleh Don Tapscott (1995) yaitu sebuah sosiopolitik dan system ekonomi yang mempunyai karakteristik sebagai sebuah ruang pengamatan 
meliputi informasi, berbagai akses instrument informasi, kapasitas informasi dan pemrosesan informasi. Komponen Ekonomi Digital yang berhasil diidentifikasi pertama kalinya yaitu industri TIK, aktivitas e-commerce, distribusi digital barang dan jasa.

Jika kita mengacu pada definisi Asian Development Bank (ADB), ekonomi digital mengacu pada berbagai kegiatan ekonomi yang menggunakan informasi dan pengetahuan digital sebagai faktor utama produksi. Ekonomi digital terkadang didefinisikan secara sempit sebagai platform online, dan aktivitas yang dilakukan pada platform tersebut. Jika ditinjau secara luas ekonomi digital International Monetary Fund (IMF) mengartikan sebagai semua aktivitas yang menggunakan data digital, semua aktivitas tersebut menjadi bagian dari ekonomi digital pada ekonomi modern. Adapun konsep Ekonomi Digital menutur Zimmerman (2000) sering digunakan untuk menjelaskan dampak global teknologi informasi dan komunikasi, tidak hanya pada internet tetapi juga pada bidang ekonomi. Selain itu ada pula pengertian Ekonomi Digital menurut PC Magazine adalah "The Impact of information technology on the economy" yang memiliki arti lebih menonjolkan pada penerapan TIK pada bidang ekonomi. Ekonomi digital merupakan ekonomi yang didasarkan kepada transaksi online berupa jaringan kabel digital atau komunikasi nirkabel, komputer, perangkat lunak, dan teknologi informasi terkait lainnya (Efraim Turban, 2018). Dari penjelasan diatas maka ekonomi digital dapat diartikan sebagai interaksi TIK dan bidang Ekonomi dalam bentuk pemanfatan TIK dalam berbagai bentuk pada berbagai kegiatan ekonomi salah satunya pemanfaatan Platform/ Applikasi.

\section{Teknologi Informasi dan Komunikasi (TIK)}

TIK memberikan peluang pada UMKM untuk menjangkau pasar yang lebih luas dengan biaya yang sangat rendah (Saridakis et al., 2018). Salah satu alat atau media yang dapat dimanfaatkan untuk meningkatkan produktivitas suatu usaha adalah teknologi. Putu Martini Dewi (2014) menyatakan Teknologi secara parsial berpengaruh positif dan signifikan terhadap pendapatan UMKM. Semakin modern teknologi yang digunakan suatu usaha semakin tiggi pendapatan yang diperoleh usaha tersebut. Pada saat sekarang ini Teknologi Informasi dan Komunikasi memiliki peranan tersendiri pada suatu usaha. Yoga S.S, et. al (2018) menyatakan manfaat terbesar yang dirasakan oleh pelaku UMKM ketika mereka menggunakan TIK dalam bentuk media online yang pertama adalah dapat meningkatkan pendapatan; manfaat kedua akan memperluas jaringan pasar; dan yang ketiga dapat mengurangi biaya pemasaran. manfaatan TIK dalam akan berbeda pada setiap UMKM, hal ini akan dipengaruhi oleh spesifikasi dan proses bisnis pada setiap UMKM (Lolanda Hamim Annisa, 2019). Dari penjabaran diatas dapat disimpulkan bahwasanya penggunaan TIK dalam proses usaha akan meningkatkan penjualan sehingga akan meningkatkan pendapatan UMKM.

Alex Capri (2018) menyatakan bahwa karakteristik pemanfaatan teknologi informasi dan komunikasi oleh UMKM di Indonesia didominasi empat bentuk TIK yaitu Cloud Computing, Social Media, E-commerce dan Sharing economy. Bentuk Cloud computing yang sering digunakan seperti Google Drive, Drob Box, Google Map dan bentuk media sosial yang digunakan seperti Facebook, WhatsApp, YouTube, Instagram, Line, dan Twitter. Untuk i di Indonesia terdapat e-commerce lokal seperti Bukalapak, Tokopedia dan Traveloka, di samping pemain besar seperti Amazon. Dampak posistif dari pemanfaatan e-commerce adalah lebih efisien, mengurangi biaya investasi, peningkatan penjualan, peningkatan relasi dengan konsumen, penetrasi pasar baru, dan pada akhirnya financial returns (Bramantyo Adi Nugroho P. W., 2019). Sharing economy di Indonesia seperti Ruang Guru, Gojek, Grab, Maxim, Kaskus. Manfaat utama bagi pelaku sharing economy adalah lebih efisien, mengurangi biaya investasi, dan peningkatan penjualan (Efraim Turban, 2018).

\section{Digital Capital}

Karaktreristik penerapan TIK pada suatu usaha dipengaruhi oleh kemampuan digital yang dimiliki suatu usaha, dan pengelolaan SDM (Human Capital) suatu usaha (Kelchevskaya N.R., 
2019). Dengan tingginya adopsi penggunaan TIK dalam suatu usaha yang dapat dilihat pada karakteristik penggunaan TIK pada usaha tersebut.

Ditinjau dari teori ekonomi digital maka melahirkan konsep modal digital ( Digital Capital) yang menjadi salah satu aspek dari ekonomi digital. Massimo Ragnedda (2018) menyatakan modal digital adalah akumulasi dari kompetensi digital (informasi, komunikasi, keselamatan, pembuatan konten dan pemecahan masalah), dan teknologi digital. Dalam sebuah perusahaan, modal digital berharga dalam bentuk karakteristik profesional atau kompetensi digital. Bughin, J. \& Manyika, J. (2013) berpendapat pengukuran dampak modal digital pada pengembangan bisnis dan menyatakan ada dua bentuk modal digital, yaitu berwujud dan tidak berwujud. Modal digital berwujud, misalnya, adalah platform pembelian online, server, outers, dan perangkat lunak internet dasar. Modal digital tidak berwujud mencakup antara lain, paten dan desain unik yang mempertimbangkan jumlah besar pengguna dan meningkatkan pengalaman digital mereka. Disimpulkan bahwa modal digital berdampak pada pertumbuhan dan persaingan usaha di era digital.

Dalam konteks ekonomi digital, Sumber daya manusia adalah faktor kunci dalam ekonomi digital (E. Shirinkina, 2018). Kelchevskaya N.R., et. al (2019) mengungkapkan bahwa informasi, pengetahuan, dan SDM digital menjadi faktor penting dalam produksi. Dalam proses produksi faktor produksi tidak saja dilihat dari ketersedian tenaga kerja tetapi kualitas dari tenaga kerja juga menjadi perhatian.

Permintaan tenaga kerja meningkat secara signifikan dengan tingkat kompetensi digital tertentu. Kompetensi digital yang paling universal, yang diperlukan untuk semua orang, menjadi tolak ukur daya saing karyawan dan ekonomi secara keseluruhan (Bannykh, 2020). Baker et. al. (2015) menemukan bahwa terdapat hubungan positif antara tingkat keterampilan digital dan pertumbuhan omset dimana tingkat keterampilan ini tidak berkaitan dengan latar belakang pendidikan formal dari tenaga kerja, tingkat keterampilan ini lebih kepada keahlian yang dimiliki oleh tenaga kerja. Saridakis et. al. (2018) menyatakan bahwa kemampuan sumber daya manusia yang dimiliki suatu UMKM berdampak pada kemampuan UMKM tersebut untuk mengadopsi suatu yang baru. Berdasarkan penjabaran diatas maka dapat dikatakan kopetensi digital yang dilihat dari ketersedian tengaga kerja dengan kopetensi digital serta pemanfaatan TIK dalam bentuk teknologi digital seperti Platform/ Applikasi berdampak baik terhadap suatu usaha.

\section{Pendapatan}

Menurut Keynes pendapatan yaitu perubahan pada jumlah faktor produksi yang digunakan dan perubahan kemampuan setiap unit faktor produksi tersebut menghasilkan pendapatan (Rosyidi, Pengantar Teori Ekonomi, 2003).

Saridakis et al., (2018) menyatakan Kinerja suatu usaha membaik ketika UMKM mengadopsi teknologi informasi dan komunikasi. Dengan pemanfaatan TIK akan membuat pasar untuk UMKM menjadi lebih besar dan meningkatkan penjualan secara online. Sejalan dengan itu Helmalia dan Afrinawati (2018) juga menyatakan peningkatan kinerja suatu usaha akan diperoleh melalui peningkatan pendapatan.

\section{Modal}

Dalam pengertian ekonomi, modal adalah barang atau uang yang bersama-sama faktor-faktor produksi seperti bangunan dan tenaga kerja menghasilkan barang-barang baru. Modal merupakan salah satu hal yang disiapkan dalam sebuah usaha. Putu Martini Dewi pada tahun 2014 menyatakan modal secara parsial berpengaruh positif dan signifikan terhadap pendapatan UMKM. Variable modal penelitian tersebut menggunakan total modal UMKM.

Modal merupakan salah satu faktor produksi. Modal mempengaruhi output melalui konsumsi input dalam proses produksi. Semakin besar modal yang digunakan maka kecenderungan peningkatan pendapatan yang diperoleh suatu usaha semakin besar. Dengan Peningkatan 
pendapatan suatu usaha tentunya akan berdampak kepada pertumbuhan usaha tersebut, Demisew G. Degefu (2018) menggunakan pertumbuhan modal sebagai ukuran pertumbuhan suatu usaha.

\section{Tenaga Kerja}

Sumber daya manusia dalam bentuk tenaga kerja merupakan salah satu faktor penting produksi. Tenaga kerja secara parsial berpengaruh positif dan signifikan terhadap pendapatan UMKM (Dewi, 2014). Semakin tinggi jenjang pendidikan tenaga kerja pada suatu usaha semakin besar pendapatan yang diperoleh usaha tersebut. Dalam menentukan daya saing suatu usaha Siti Rahmana Bintari \&, Lilies Setiartiti (2013) mendiskripsikan unsur tenaga kerja yang menentukan dalam sebuah usaha yaitu Jumlah tenaga kerja, Pendidikan tenaga kerja, Upah tenaga kerja, Jam kerja tenaga kerja. Pendidikan tenaga kerja didefinisikan sebagai Pendidikan formal yang dimiliki oleh tenaga kerja. Daya saing salah satunya dapat dilihat dari faktor permintaan yang digambarkan dengan jumlah permintaan/ penjualan produk. Jumlah permintaan akan berkorelasi terhadap pendapatan suatu usaha. Ini sejalan dengan penelitian yang dilakukan oleh Dewi Putu Martini (2014) yang menyatakan Tenaga kerja secara parsial berpengaruh positif dan signifikan terhadap pendapatan UMKM. Semakin tinggi jenjang pendidikan tenaga kerja pada suatu usaha semakin besar pendapatan yang diperoleh usaha tersebut. Pendidikan tenaga kerja didefinisikan sebagai Jenjang Pendidikan formal yang dimiliki oleh tenaga kerja.

Waktu yang dibutuhkan untuk merasakan dampak peningkatan kinerja pada UMKM berbedabeda tergantung kemampuan dari sumber daya manusia UMKM tersebut. Sedangkan untuk peningkatan kinerja perusahaan dapat diperoleh melalui peningkatan pendapatan (Helmalia dan Afrinawati, 2018). Berdasarkan uraian diatas kemampuan sumber daya manusia pada UMKM khususnya kemampuan/ keterampilan digital sangatlah berdampak pada UMKM. Dampak akan dirasakan pada kinerja usaha yang dapat dilihat dari pendapatan UMKM. Sedangkan kemampuan SDM yang dimaksud merupakan keahlian tertentu yang dimiliki oleh tenaga kerja pada UMKM.

\section{Kerangka konseptual}

Pada penelitian ini akan melihat dampak pemanfaatan teknologi digital oleh UMKM terhadap pendapatan (revenue) UMKM dengan pendekatan pada fungsi produksi Cobb-Douglas yang memiliki konsep yang lebih sederhana tentang ekonomi di mana output produksi (Y) ditentukan oleh jumlah dari modal yang diinvestasikan $(\mathrm{K})$ dan jumlah tenaga kerja (L) yang terlibat dalam produksi. fungsi produksi Cobb-Douglas juga mempertimbangkan parameter yang menunjukkan peningkatan teknologi.

Dari penjabaran diatas maka dalam penelitian ini kerangka konseptual yang digunakan dapat digambarkan sebagai berikut;

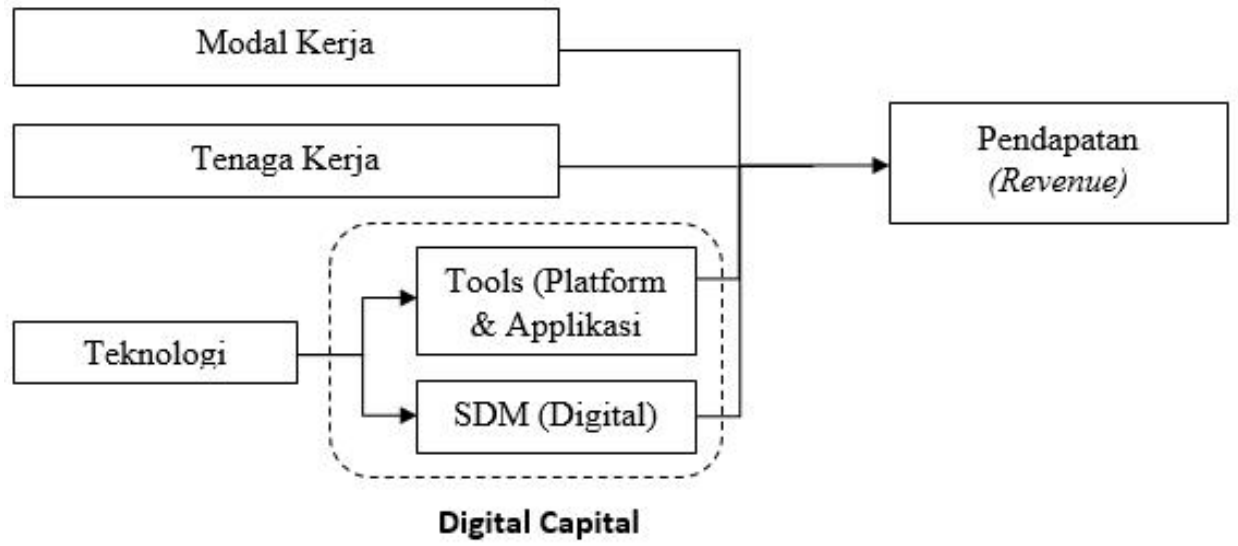

Gambar 1. Kerangka Konseptual 


\section{METODE PENELITIAN}

Penelitian ini merupakan penelitian Kuantitatif-Deskriptif untuk menjelaskan Pengaruh Pandemi Covid-19 terhadap dampak implementasi Ekonomi Digital terhadap UMKM terutama terhadap pendapatan UMKM. UMKM yang diteliti difokuskan kepada UMKM pada sektor kuliner di kota Padang yang telah beroperasi sebelum Covid-19 melanda Indonesia dan menjadikan minuman olahan kopi sebagai produk utamanya. Penelitain dilakukan metode Survei lansung kepada responden yang dilakukan dengan menggunakan kuisioner. Teknik penentuan sampel menggunakan teknik Purposife Sampling. Penentuan jumlah sampel dihitung menggunakan rumus slovin (Riduwan, 2010) dengan rumus sebagai berikut:

$$
\mathrm{n}=\mathrm{N} /\left(1+\mathrm{N} \cdot \mathrm{e}^{\wedge} 2\right)
$$

Populasi UMKM sektor kuliner dengan produk utama minuman olahan dengan bahan baku kopi di Kota Padang adalah 149 UMKM. Dengan menggunakan rumus slovin maka diperoleh ukuran sampel 59,8 sampel, dibulatkan menjadi 60 sampel. Selanjutnya dicari pengambilan sampel bertingkat dengan rumus (Riduwan, 2010) :

$$
\mathrm{n}_{-} \mathrm{i}=\mathrm{N} \_\mathrm{i} /(\mathrm{N} . n)
$$

Rincian populasi UMKM dalam penelitian ini adalah 11 usah menengah, 40 usaha kecil dan 98 usaha mikro, Dengan menggunakan pengambilan sampel bertingkat maka diperoleh ukuran sampel usaha menengah adalah 5 sampel, Usaha kecil sebanyak 17 sampel dan usaha mikro sebanyak 40 sampel. Penentuan sampel yang menjadi responden pada penelitian ini nantinya didasarkan pada angka random yang didapatkan dari penggunaan fungsi randbetween pada software Microsoft Excel.

Penelitian ini dilakukan dengan metoda analisis kuantitatif. Analisis data pada penelitian ini menggunakan analisis regresi linear berganda dengan bantuan Software StataMP 15 terhadap data yang dikumpulkan. Analisis data dilakukan dengan menggunakan uji simultan $(F$-test) dan uji parsial ( $t$-test) untuk mengetahui pengaruh antar variabel. Pengaruh antara variabel akan dilihat pada kondisi sebelum pandemic covid-19 terjadi, saat pandemic covid-19 (awal Pandemi) dan kondisi setelah new normal diterapkan.

Pada penelitian ini akan melihat dampak pemanfaatan teknologi digital oleh UMKM terhadap pendapatan (revenue) UMKM dengan pendekatan pada fungsi produksi Cobb-Douglas, maka bentuk matematis secara dari analisis regresi linier berganda dapat digambarkan persamaan berikut ini:

$$
L n \boldsymbol{Y}=\boldsymbol{\beta}_{o}+\boldsymbol{\beta}_{1} \operatorname{Ln} \boldsymbol{K}+\boldsymbol{\beta}_{2} \operatorname{Ln} \boldsymbol{L}+\boldsymbol{D}_{D C}+\boldsymbol{e}_{\boldsymbol{i}}
$$

Dimana $\boldsymbol{Y}$ diartikan sebagai revenue atau Total Pendapatan yang nantinya dihitung dalam satuan Rupiah, $\boldsymbol{K}$ adalah Modal yang digunakan untuk produksi khususnya modal kerja yang dihitung dalam satuan Rupiah, $\boldsymbol{L}$ adalah jumlah tenaga kerja dalam satuan orang. Variabel teknologi yang dimaksud dalam peneliltian ini adalah variabel dummy Digital Capital $\left(\boldsymbol{D}_{\boldsymbol{D C}}\right)$. Digital Capital yang merupakan perwujudan dari pemanfaatan SDM digital dan pemanfaatan Platform/ aplikasi digital (TIK) yang dilakukan secara simultan (Massimo Ragnedda, 2020). Pemanfaatan SDM digital yang diartikan pemanfaatan SDM yang memiliki kemampuan digital Penggunaan Platform/ Applikasi TIK yang ditinjau pada penelitian ini terdiri dari empat jenis teknologi yaitu, Cloud computing, Social media, E-commerce, Sharing economy (Capri, 2018). $\boldsymbol{e}_{\boldsymbol{i}}$ adalah error atau sisaan atau simpangan dan $\boldsymbol{\beta}_{\boldsymbol{o}}, \boldsymbol{\beta}_{\mathbf{1}}, \boldsymbol{\beta}_{\mathbf{2}}$ adalah Koefisien konstanta dari persamaan tersebut. 
Tabel 1. Divinisi Operasional Variabel

\begin{tabular}{|c|c|c|c|c|}
\hline Variabel & Indikator & Referensi & $\begin{array}{c}\text { Skala } \\
\text { Pengukuran }\end{array}$ & $\begin{array}{c}\text { Metode } \\
\text { Pengukuran }\end{array}$ \\
\hline $\begin{array}{l}\text { Pendapatan } \\
\text { /Revenue } \\
(\boldsymbol{Y})\end{array}$ & $\begin{array}{l}\text { Total pendapatan dari } \\
\text { seluruh penjualan produk } \\
\text { dalam satu bulan }\end{array}$ & $\begin{array}{l}\text { Dewi (2014), Baker } \\
\text { (2015), (Maria } \\
\text { Carvalho (2018), } \\
\text { (Selase et al., 2019). }\end{array}$ & Rupiah & Kuisioner \\
\hline Modal $(\boldsymbol{K})$ & $\begin{array}{l}\text { Biaya pengeluaran } \\
\text { pembelian bahan produksi } \\
\text { dalam satu bulan }\end{array}$ & $\begin{array}{l}\text { (Dewi, 2014). Satyo } \\
\text { Nugroho (2014) }\end{array}$ & Rupiah & Kuisioner \\
\hline $\begin{array}{l}\text { Tenaga } \\
\text { Kerja }(\boldsymbol{L})\end{array}$ & $\begin{array}{l}\text { Tenaga kerja yang bertugas } \\
\text { dan memiliki keahlian } \\
\text { dalam meracik \& membuat } \\
\text { kuliner }\end{array}$ & $\begin{array}{l}\text { Siti Rahmana Bintari } \\
\& \text {, Lilies Setiartiti } \\
\text { (2013), } \\
\text { E. Shirinkina (2018) }\end{array}$ & $\begin{array}{l}\text { Jumlah } \\
\text { Orang }\end{array}$ & Kuisioner \\
\hline $\begin{array}{l}\text { Dummy } \\
\text { Digital } \\
\text { Capital } \\
\left(\boldsymbol{D}_{\boldsymbol{D C}}\right)\end{array}$ & $\begin{array}{l}\text { Memiliki SDM yang } \\
\text { Memiliki keahlian } \\
\text { digital dan bertugas } \\
\text { sebagai pengelola/ } \\
\text { operator TIK } \\
\text { Menggunakan/ } \\
\text { Mengakses dan } \\
\text { berinteraksi/ }\end{array}$ & $\begin{array}{l}\text { (Massimo Ragnedda, } \\
\text { 2020),(Ragnedda, } \\
\text { 2018), (Bughin, 2013), } \\
\text { Baker et. al. (2015), } \\
\text { (Massimo Ragnedda, } \\
\text { 2020), Alex Capri } \\
\text { (2018), (Efraim } \\
\text { Turban, 2018). }\end{array}$ & Ya/tidak & Kuisioner \\
\hline
\end{tabular}

\section{HASIL DAN PEMBAHASAN}

\section{Uji Asumsi Klasik}

Berdasarkan analisis uji normalitas dengan menggunakan metode Skewness-Kurtosis test for Normality. Pada tabel 2 terlihat bahwa sebelum Covid-19 diperoleh nilai Prob $>$ chi2 dari uji normalitas sebesar 0,4566. Kondisi saat Covid-19 diperoleh nilai Prob $>$ chi2 dari uji normalitas sebesar 0,0853. Dan pada kondisi New Normal diperoleh nilai Prob $>$ chi2 dari uji normalitas sebesar 0,4073. Pada setiap kondisi diperoleh hasil lebih besar dari taraf signifikansi 0,05 sehingga dapat disimpulkan bahwa uji tes normalitas pada penelitian ini adalah terdistribusi normal.

Tabel 2. Uji Normalitas

\begin{tabular}{cccccc}
\hline Variable & Obs & $\operatorname{Pr}($ Skewness) & $\operatorname{Pr}($ Kurtosis) & adj chi2(2) & Prob>chi2 \\
\hline $\begin{array}{c}\text { UR } \\
\text { (Sebelum Covid-19) }\end{array}$ & 62 & 0.2460 & 0.6867 & 1.57 & 0.4566 \\
\hline $\begin{array}{c}\text { UR } \\
\left(\begin{array}{c}\text { Saat Covid-19/ Awal } \\
\text { Pandemi) }\end{array}\right.\end{array}$ & 62 & 0.1530 & 0.0866 & 4.92 & 0.0853 \\
\hline $\begin{array}{c}\text { UR } \\
\text { (New Normal) }\end{array}$ & 62 & 0.2510 & 0.5228 & 1.80 & 0.4073 \\
\hline
\end{tabular}

Berdasarkan Analisis Uji heteroskedastisitas menggunakan metode Breusch-Pagan test for heteroskedasticity dengan asumsi $\mathrm{H}_{\mathrm{o}}$ adalah Constant variance atau homoskedastis. Pada tabel 3 terlihat bahwa sebelum Covid-19 diperoleh nilai $P r o b>c h i 2$ sebesar 0,3695. Kondisi saat Covid-19 diperoleh nilai Prob>chi2 sebesar 0,3766. Sedangkan pada kondisi New Normal diperoleh nilai 
Prob $>$ chi2 sebesar 0,2396. Pada setiap konsisi diperoleh nilai Prob $>$ chi2 lebih besar dari taraf signifikansi 0,05 sehingga tidak tolah $\mathrm{H}_{\mathrm{o}}$ dan dapat disimpulkan tidak terjadi heteroskedastisitas.

Tabel 3. Uji Heteroskedasitas

\begin{tabular}{cccl}
\hline Kondisi & chi2 (1) & Prob $>$ chi2 & Keterangan \\
\hline (Sebelum Covid-19) & 0.81 & 0.3695 & tidak terjadi heteroskedastisitas \\
\hline (Saat Covid-19/ Awal Pandemi) & 0.78 & 0.3766 & tidak terjadi heteroskedastisitas \\
\hline (New Normal) & 1.38 & 0.2396 & tidak terjadi heteroskedastisitas \\
\hline
\end{tabular}

Dari hasil uji Multikolinearitas didapatkan hasil VIF pada setiap variable independent maupun nilai rata-rata VIF berada dibawah 5 sehingga dapat disimpulkan bahwa tidak terjadi multikolinearitas. Berdasarkan tabel 4 dapat diketahui pada setiap kondisi diperoleh hasil VIF dan rata-rata VIF setiap variable independent kecil dari 5 sehingga disimpulkan tidak terjadi multikolinearitas.

Tabel 4. Uji Multikolinearitas

\begin{tabular}{|c|c|c|c|c|}
\hline Kondisi & Variable & VIF & 1/VIF & Keterangan \\
\hline \multirow{4}{*}{$\begin{array}{l}\text { (Sebelum Covid- } \\
19)\end{array}$} & Modal & 1.52 & 0.657183 & tidak terjadi Multikolinearitas \\
\hline & Tenaga Kerja & 1.48 & 0.675895 & tidak terjadi Multikolinearitas \\
\hline & Digital Capital & 1.05 & 0.953488 & tidak terjadi Multikolinearitas \\
\hline & Mean VIF & 1.35 & & tidak terjadi Multikolinearitas \\
\hline \multirow{4}{*}{$\begin{array}{l}\text { (Saat Covid-19/ } \\
\text { Awal Pandemi) }\end{array}$} & Modal & 1.43 & 0.698684 & tidak terjadi Multikolinearitas \\
\hline & Tenaga Kerja & 1.29 & 0.773850 & tidak terjadi Multikolinearitas \\
\hline & Digital Capital & 1.15 & 0.869317 & tidak terjadi Multikolinearitas \\
\hline & Mean VIF & 1.29 & & tidak terjadi Multikolinearitas \\
\hline \multirow{4}{*}{ (New normal) } & Modal & 1.83 & 0.546725 & tidak terjadi Multikolinearitas \\
\hline & Tenaga Kerja & 1.76 & 0.568761 & tidak terjadi Multikolinearitas \\
\hline & Digital Capital & 1.17 & 0.856405 & tidak terjadi Multikolinearitas \\
\hline & Mean VIF & 1.58 & & tidak terjadi Multikolinearitas \\
\hline
\end{tabular}

\section{Uji Regresi}

Pada tabel 5 terlihat persamaan regresi dari hasil analisis regresi pada setiap kondisi pengamatan. Dari analisis regresi didapatkan persamaan regresi sebagai berikut

Tabel 5. Persamaan Regresi

\begin{tabular}{ccc}
\hline Kondisi & Keterangan & R-squared \\
\hline (Sebelum & Total Pendapatan $=3.4780+0,7760$ Modal $+0,1319$ Tenaga Kerja & 0.8842 \\
Covid-19) & $+0,1435$ Digital Capital & \\
\hline (Saat Covid-19/ & Total Pendapatan $=2,1609+0,8846$ Modal $+0,1498$ Digital Capital & 0.9158 \\
Awal Pandemi) & Total Pendapatan $=2,8049+0,8328$ Modal $+0,1657$ Digital Capital & 0.9262 \\
\hline (New Normal $)$ &
\end{tabular}


Berdasarkan persamaan yang diperoleh nilai konstanta pada kondisi sebelum Covid-19 sebesar 3.4780. dapat diartikan bahwa jika diasumsikan tidak ada pengaruh dari variabel Modal, Tenaga Kerja dan Digital Capital maka Total pendapatan (revenue) adalah 3.4780. Nilai konstanta pada kondisi saat Covid-19 sebesar 2,1609. dapat diartikan bahwa jika diasumsikan tidak ada pengaruh dari variabel Modal, Tenaga Kerja dan Digital Capital maka Total pendapatan (revenue) adalah 2,1609. Nilai konstanta pada kondisi New Normal sebesar 2,8049. dapat diartikan bahwa jika diasumsikan tidak ada pengaruh dari variabel Modal, Tenaga Kerja dan Digital Capital maka Total pendapatan (revenue) adalah 2,8049. Dengan kondisi ini dapat dilihat bahwa kondisi pandemic Covid-19 menurunkan total pendapatan. Namun kondisi New Normal dapat mempengaruhi total pendapatan menjadi lebih baik jika dibandingkan total pendapatan pada saat kondisi Covid-19.

Pada tabel 5 terlihat bahwa nilai koefisien determinan $\left(\mathrm{R}^{2}\right)$ pada kondisi saat covid-19 meningkat dibandingkan nilai koefisien determinasi pada kondisi sebelum covid-19, nilai koefisien determinasi ini pun semakin meningkat disaat kondisi new normal. ini menunjukkan bahwa pandemi covid-19 berdampak positif terhadap kemampuan model yang dibuat untuk menjelaskan variabel dependen.

Pada kondisi sebelum Covid-19 diperoleh $\mathrm{R}^{2}$ sebesar 0.8842 yang dapat diartikan bahwa model yang telah terbentuk dapat menjelaskan variable dependen sebesar $88,42 \%$. Total Pendapatan dapat dijelaskan oleh model sebesar $88,42 \%$ dan sisanya dijelaskan oleh variable diluar model. Pada kondisi saat Covid-19 diperoleh $\mathrm{R}^{2}$ sebesar 0.9158 yang dapat diartikan bahwa model yang telah terbentuk dapat menjelaskan variable dependen sebesar 91,58\%. Total Pendapatan dapat dijelaskan oleh model sebesar $91,58 \%$ dan sisanya dijelaskan oleh variable diluar model. Pada kondisi saat Covid-19 diperoleh $\mathrm{R}^{2}$ sebesar 0.9262 yang dapat diartikan bahwa model yang telah terbentuk dapat menjelaskan variable dependen sebesar 92,62\%. Total Pendapatan dapat dijelaskan oleh model sebesar $92,62 \%$ dan sisanya dijelaskan oleh variable diluar model.

\section{Uji F}

Tabel 6. Uji F

\begin{tabular}{lccc}
\hline Output & Sebelum Covid-19 & Saat Covid-19 & New Normal \\
\hline Prob $>$ F & 0.0000 & 0.0000 & 0.0000 \\
\hline
\end{tabular}

Dilihat pada tabel 6 secara simultan $\mathrm{P}_{\text {valuae }}$ yang diperoleh nilai kecil dari tingkat siknifikansi 0,05 . Secara simultan $P_{\text {valuae }}$ pada kondisi sebelum covid-19, saat covid-19 terjadi, dan saat kondisi new normal memiliki nilai 0,000. Dapat diartikan bahwa secara simultan variabel independen yang digunakan secara signifikan berpengaruh terhadap variabel independen pada setiap kondisi yang ada, baik itu pada kondisi sebelum covid-19, saat covid-19 dan new normal. Persamaan regresi yang digunakan juga dapat dikatakan sudah tepat dan dapat dimanfaatkan untuk uji penelitian.

\section{Uji t}

Secara parsial, $\mathrm{P}_{\text {valuae }}$ dari $\mathrm{t}_{\text {statistik }}$ yang diperoleh pada setiap variabel independen memiliki nilai yang beragam. Keragaman ini juga dilihat pada kondisi sebelum covid-19, saat covid-19, dan saat kondisi new normal. 
Tabel 6. Uji t

\begin{tabular}{ccccccc}
\hline \multirow{2}{*}{ Variabel } & \multicolumn{2}{c}{ Sebelum Covid-19 } & \multicolumn{2}{c}{ Saat Covid-19 } & \multicolumn{2}{c}{ New Normal } \\
\cline { 2 - 7 } & Koefisien & $\mathrm{P}>|\mathrm{t}|$ & Koefisien & $\mathrm{P}>|\mathrm{t}|$ & Koefisien & $\mathrm{P}>|\mathrm{t}|$ \\
\hline Modal & 0.7760195 & 0.000 & 0.8846897 & 0.000 & 0.8328792 & 0.000 \\
\hline Tenaga Kerja & 0.1319550 & 0.020 & 0.0826399 & 0.144 & 0.1034530 & 0.083 \\
\hline Digital Capital & 0.1435249 & 0.036 & 0.1498340 & 0.055 & 0.1657995 & 0.028 \\
\hline _cons & 3.578 .067 & 0.000 & 2.160 .954 & 0.000 & 2.804 .969 & 0.000 \\
\hline
\end{tabular}

Secara parsial variabel independent Modal tidak mengalami perubahan $\mathrm{P}_{\text {valuae }}$ pada setiap kondisi. Ini menandakan variabel Modal berpengaruh siknifikan terhadap pendapatan dan siknifikan ini tidak dipengarahi oleh pandemi covid-19.

Secara parsial variabel independent Tenaga Kerja mengalami perubahan $\mathrm{P}_{\text {valuae }}$ pada kondisi pandemi covid-19. $\mathrm{P}_{\text {valuae }}$ pada kondisi sebelum pandemi covi-19 kecil dari taraf signifikansi 0,05. Kondisi ini diartikan Tenaga Kerja berpengaruh positif secara siknifikan terhadap pendapatan. Namun pada kondisi pandemic covid-19 dan now normal, $\mathrm{P}_{\text {valuae }}$ yang diperoleh pada variabel independent Tenaga Kerja mengalami perubahan. Pada saat pandemic covid-19 dan new normal diperoleh besar dari taraf signifikansi 0,05. Dapat diartikan pada kondisi pandemi covid-19 dan now normal variabel Tenaga Kerja tidak berpengaruh terhadap pendapatan.

Secara parsial variabel dummy Digital Capital yang diartikan pemanfaatan SDM digital dan Platform/ Applikasi Digital dilakukan secara simultan. sebagai pemanfaatan tenaga kerja dengan kemampuan TIK yang khusus digunakan pada pengelolaan TIK serta pemanfaatan Platform/ Applikasi yang dilakukan secara simultan. Variabel dummy Digital Capital tidak mengalami perubahan yang siknifikan pada $\mathrm{P}_{\text {valuae }}$ di setiap kondisi. $\mathrm{P}_{\text {valuae }}$ pada kondisi sebelum pandemi covid-19, saat pandemic covid-19 dan kondisi new normal. Pada kondisi sebelum pandemi covid$19 \mathrm{P}_{\text {valuae }}$ berada pada nilai yang kecil dari taraf signifikansi 0,05 , saat pandemic covid- $19 \mathrm{P}_{\text {valuae }}$ berada pada nilai yang besar dari taraf signifikansi 0,05 namun kecil dari taraf signifikansi 0,10 . Pada kondisi new normal diterapkan $P_{\text {valuae }}$ berada pada nilai yang kecil dari taraf signifikansi 0,05 . $\mathrm{P}_{\text {valuae }}$ sebelum pandemi covid-19 sebesar 0.036. Pada kondis saat pandemi covid-19 terjadi perubahan $\mathrm{P}_{\text {valuae }}$ menjadi 0.055 namun saat diberlakukannya kondisi new normal nilai $\mathrm{P}_{\text {valuae }}$ berubah menjadi lebih baik sebesar 0.028. Kondisi ini diartikan bahan baku berpengaruh positif secara siknifikan terhadap pendapatan. variabel dummy Digital Capital berpengaruh siknifikan terhadap pendapatan dan pandemi covid-19 mempengaruhi dampak dari variabel dummy Digital Capital terhadap pendapatan. 


\section{PENUTUP}

\section{Kesimpulan}

Pandemi Covid-19 berdampak buruk terhadap UMKM, mengakibatkan menurunkan pendapatan pada UMKM. Penetapan kondisi New Normal berdampak baik terhadap UMKM, dapat memperbaiki pendapatan UMKM menjadi lebih baik.

Pada kondisi sebelum Covid-19 secara simultan Modal, jumlah karyawan, dan Digital Capital berpengaruh siknifikan terhadap Total pendapatan UMKM. Pada kondisi saat Covid-19 melanda secara simultan Modal, dan Digital Capital berpengaruh siknifikan terhadap Total pendapatan UMKM. Pada kondisi saat New Normal secara simultan Modal, dan Digital Capital berpengaruh siknifikan terhadap Total pendapatan UMKM.

Pandemi covid-19 tidak mempengaruhi dampak Modal dan Digital Capital secara parsial terhadap pendapatan UMKM. Pandemi covid-19 mempengaruhi dampak Tenaga Kerja secara parsial terhadap pendapatan UMKM.

\section{Saran}

Bagi pelaku UMKM, sangat diperlukannya upaya yang lebih untuk memanfaatkan Platform/Applikasi digital dan meningkatkan kualitas SDM dibidang digital secara simultan. khususnya perihal pengetahuan, keahlian teknis dan wawasan tentang pemanfaatan TIK pada pelaku dan tenaga kerja yang terlibat dalam pengelolaan TIK yang dipergunakan oleh UMKM. hal ini juga dapat mendukung implementasi ekonomi digital berupa pemanfaatan TIK pada UMKM. Pemanfaatan Platform/Applikasi digital dengan SDM yang memiliki pengetahuan, keahlian teknis dan wawasan tentang pemanfaatan TIK juga dapat berperan positif dalam upaya menghadapi perubahan zaman tak terduga seperti dampak pandemic covid-19 yang terjadi pada saat ini.

Bagi pemerintah perlu memberikan perhatian khusus dalam upaya meningkatkan Pemanfaatan Platform/Applikasi digital dan kualitas SDM pada UMKM. Peningkatan kualitas SDM yang dimaksut adalah perihal pengetahuan, dan wawasan serta kemampuan teknis terhadap pemanfaatan TIK pada pelaku dan tenaga kerja yang terlibat dalam UMKM. Perhatian dapat diimplementasikan dalam pemberian pendampingan teknis, pelatihan teknis dalam pemanfaatan TIK pada suatu usaha.

Bagi peneliti dan akademisi perlu mempertimbangkan perkembangan Teknologi Informasi dan Komunikasi yang sangat dinamis diantaranya berupa perkembangan platform atau Applikasi yang memiliki karakteristik masing-masing. Dengan perkembangan yang sangat dinamis tersebut tentunya tidak menutup kemungkinan akan muncul beberapa variabel baru yang dapat mempengaruhi dampak pemanfaatan Teknologi Informasi dan Komunikasi pada UMKM. Tentunya perlu dikemudian hari dilakukan penelitian lebih lanjut agar dapat mengakomodir perkembangan Teknologi Informasi dan Komunikasi yang ada.

\section{F. DAFTAR PUSTAKA}

Afenya, M. S., A. E.-R.-A. (2019). Impact of Technology Adoption and Its Utilization on SMEs in Ghana. International Journal of Small and Medium Enterprises, 1-13.

Baker, G. L. (2015). Digital Capabilities in SMEs: Evidence Review and Re-Survei of 2014 Small Business Survei respondents,. BMG Research and Durham University.: BIS Research Paper No 247.

Bannykh, G. (2020). Digital Capital and the Labor Market: Factors of Mutual Influence. Advances in Economics, Business and Management Research, volume 128, 2946-2953.

BPS. (2019). Analisis Hasil Se2016 Lanjutan Potensi Peningkatan Kinerja Usaha Mikro Kecil. Jakarta: Badan Pusat Statistik. 
Bramantyo Adi Nugroho, P. W. (2019). Analisis Persepsi Usaha Mikro Terhadap Pemanfaatan Media Daring di Kota Samarinda. Jurnal Riset Pembangunan Volume 1, 79-89.

Bughin, J. \&. (2013). Measuring the full impact of Digital Capital. Mackinsey and Co.

Capri, A. (2018). Micro And Small Businesses In Indonesia's Digital Economy Keys To Developing New Skills And Human Capital. Jakarta: The Asia Pacific Foundation Of Canada.

Chege, S. M., Wang, D., \& Suntu, S. L. (2020). Impact of information technology innovation on firm performance in Kenya. Information Technology for Development vol. 26, 316-345

Degefu, D. G. (2018). Factors That Determine the Growth of Micro and Small Enterprises: In the Case of Hawassa City, Ethiopia. Scientific Research Publishing, 185-200.

Deloitte. (2015). UMKM Pemicu Kemajuan Indonesia : Instrumen Pertumbuahan Nusantara. Sydney: Deloitte Access Economics.

Dewi, P. M. (2014). Pengaruh Modal, Tingkat Pendidikan dan Teknologi Terhadap Pendapatan Usaha Mikro Kecil dan Menengah (Umkm) di Kawasan Imam Bonjol Denpasar Barat. EJurnal Ekonomi Pembangunan Universitas Udayana Vol. 3, No. 12, hal 576-585.

Donou-Adonsou, F. (2019). Technology, education, and economic growth in Sub-Saharan Africa. Telecommunications Policy, 1.

E. Shirinkina, A. K. (2018). Management of human capital in the national economy: Estimation and simulation. Revista Espacios, 28. Vol. 39 (Number 44)..

Efraim Turban, J. O.-P. (2018). Electronic Commerce 2018 A Managerial and Social Networks Perspective 9 th. spinger.

George Saridakis, Y. L. (2018). Industry characteristics, stages of E-commerce communications, and entrepreneurs and SMEs revenue growth. Technological Forecasting \& Social Change, 56-66.

Helmalia, A. (2018). Pengaruh E-Commerce Terhadap Peningkatan Pendapatan Usaha Mikro Kecil dan Menengah di Kota Padang. JEBI (Jurnal Ekonomi dan Bisnis Islam) - Volume 3, No. 2.

Indrawan, R. (2019). Sinergitas Pengembangan KUMKM melalui Penguatan Peran Antar Lembaga. Sanur: Kementrian Koperasi dan Usaha Mikro Kecil dan Menengah Republik Indonesia.

Kelchevskaya N.R., S. E. (2019). Estimation of interrelation of components of human capital and level of digitalization of industrial enterprises by method of modeling of structural equations. Advances in Economics, Business and Management Research, volume 81, , 135140.

Kelchevskaya N.R., S. E. (2019). Evaluation of Digital Development of Human Capital of Enterprises. Advances in Social Science, Education and Humanities Research, volume 298, , 446-449.

Lolanda Hamim Annisa, M. E. (2019). Impact of Alignment between Social Media and Business Processes on SMEs' Business Process Performance: A Conceptual Model . Procedia Computer Science 161, 1106-1113. 
Massimo Ragnedda, M. L. (2020). Digital Capital: A Bourdieusian Perspective on the Digital Divide. UK: Emerald Group Publishing.

Nida Masroor, M. A. (2019). SMEs in the Contemporary Era of Global Competition. Procedia Computer Science 158, 632-641.

ORCD. (2020). Coronavirus (COVID-19): SME Policy Responses. Organisation for Economic Co-operation and Development

Ragnedda, M. (2018). Conceptualizing Digital Capital. Telematics and Informatics vol. 35, 23662375 .

Riduwan. (2010). Metode \& Teknik Penyusunan Tesis. Bandung: Alfabeta.

Rodriguez, M., Peterson, R. M., \& Ajjan, H. (2014). Crm/Social Media Technology: Impact on Customer Orientation Process and Organizational Sales Performance. Journal of Marketing Development and Competitiveness vol. 8, 85-97

Siti Rahmana Bintari, \&. L. (2013). Pengukuran Daya Saing Usaha Mikro Kecil dan Menengah Menyongsong Masyarakat Ekonomi Asean. Jurnal Ekonomi dan Studi Pembangunan Volume 14, Nomor 2, 153-162.

Yoga Satria Siaga, J. J. (2018). Penerapan dan Pemanfaatan Media Online dalam Pengembangan Sistem Pemasaran UMKM (Agroindustri) di Kabupaten Jember. Seminar Nasional Program Studi AgribisnisFakultas Pertanian Universitas Jember,, (hal. hal. 433-441). Jember. 